\title{
Eradicating leukemia stem cells
}

\section{By Chris Cain, Staff Writer}

An international team has shown that inhibiting the oncoprotein BCL6 improves the efficacy of tyrosine kinase inhibitors in cell culture and mouse models of acute lymphoblastic leukemia and chronic myelogenous leukemia. ${ }^{1,2}$ This suggests that BCL6 inhibitors already being developed by Forma Therapeutics Inc. and the Leukemia \& Lymphoma Society to treat diffuse large B cell lymphoma could also be used to shorten the time patients with $B C R-A B L$-positive leukemias need to be on the tyrosine kinase inhibitors.

Patients with chronic myelogenous leukemia (CML) or $B C R-A B L$ tyrosine kinase-positive acute lymphoblastic leukemia (ALL) are treated with tyrosine kinase inhibitors (TKIs), including

"The goal here is not to kill the proliferating leukemia cells, but to eradicate the rare leukemia stem cells, which would evade TKI treatment."

-Markus Müschen, University of California, San Francisco

To test the functional consequences of BCL6 expression, Müschen needed an inhibitor of the protein-a difficult task because BCL6 is intracellular and does not have enzymatic activity. Thus, pharmacological inhibition would require disrupting its protein-protein interactions with other transcriptional regulators.

The solution came from Ari Melnick, associate professor of medicine at Weill Cornell Medical College, who had been working on peptidebased BCL6 inhibitors since 2004. ${ }^{3}$ In 2009, Melnick synthesized a peptide of $42 \mathrm{D}$-amino acids that potently inhibited DLBCL growth in mice. ${ }^{4}$

In cultured, Gleevec-resistant ALL cells, Müschen's group showed that this BCL6 inhibitor restored sensitivity to Gleevec in comparison with vehicle control. In xenograft mice with ALL cells, Tasigna plus the BCL6 inhibitor prolonged survival in comparison with Tasigna alone.

Results were published in Nature.

Müschen next looked at BCL6 levels in TKI-treated CML samples because that cancer also is driven by $B C R$ $A B L$. In purified CML-initiating cells, $B C L 6$ was upregulated after Gleevec treatment. In xenograft mouse models of CML, the BCL6 inhibitor improved overall survival in comparison with vehicle controls. CML was undetectable in three of ten mice after treatment, suggesting that inhibiting BCL6 could completely eliminate CML-initiating cells in this model. In eight primary human CML samples, the BCL6 inhibitor selectively eradicated the rare CML-initiating cells.

Gleevec imatinib and Tasigna nilotinib from Novartis AG and Sprycel dasatinib from Bristol-Myers Squibb Co. and Otsuka Pharmaceutical Co. Ltd.

However, the drugs do not kill leukemia-initiating cells, and as a result the cancers relapse if drug resistance emerges or if patients stop treatment.

"If Philadelphia chromosome-positive ALL comes back, you can go from Gleevec to nilotinib, then dasatinib and potentially other tyrosine kinase inhibitors, but it's a disease that keeps coming back unless one [manages] to kill the last cells by bone marrow transplantation, which is associated with relatively high treatment mortality," said Markus Müschen, professor of laboratory medicine at the University of California, San Francisco. "And only few patients achieve complete remission that allows them to even receive bone marrow transplantation."

A team led by Müschen sought to understand why leukemiainitiating cells are not killed by TKIs. The group first performed gene expression analyses on $B C R-A B L$-positive ALL cells treated with Gleevec and were surprised to find that $B C L 6$ expression was about 90 -fold higher than in untreated cells.

Previously, high levels of BCL6 (B cell CLL lymphoma 6) were thought to be associated only with diffuse large B cell lymphoma (DLBCL) and not with other hematological malignancies. BCL6 is a transcription factor that promotes cell survival by suppressing the TRP53 (p53) tumor suppressor gene.
"The goal here is not to kill the proliferating leukemia cells, but to eradicate the rare leukemia stem cells, which would evade TKI treatment," said Müschen.

Results were published in the Journal of Experimental Medicine. Melnick was a coauthor on both papers.

Müschen noted that in CML, treatment with a BCL6 inhibitor alone was enough to kill leukemia-initiating cells, which suggests that even low levels of BCL6 are likely to play a role in the disease. He said that although TKIs are essential to control proliferating CML cells in patients, "promotion of leukemia-initiating cell survival may be an unwanted effect of TKI treatment."

"To date, the preclinical research has clearly supported DLBCL as a valid indication for BCL6 inhibition," said Louis DeGennaro, EVP and chief mission officer of the Leukemia \& Lymphoma Society (LLS). "These two papers now expand the potential utility of a BCL6 inhibitor to include Philadelphia chromosome-positive ALL and CML. The data also imply that a drug combination strategy of TKIs plus a BCL6 inhibitor might eliminate both bulk disease and the leukemia-initiating cells."

The society provided grant funding that supported both studies.

\section{A tough target}

Müschen and Melnick are running further preclinical studies to move the peptide into the clinic. Müschen noted the challenge to its development is that "the cost of production is almost prohibitive for this peptide." 


\section{ANALYSIS}

Last year, Melnick published the first proof of concept that BCL6 can be inhibited by a small molecule, although the compounds had micromolar half-maximal inhibitory concentration $\left(\mathrm{IC}_{50}\right)$ values and were not potent enough to be clinical candidates. ${ }^{5}$

In March 2010, LLS and Forma partnered to improve the potency of these initial compounds and to screen for novel chemical scaffolds that inhibit BCL6.

"Our approach in working with LLS is to advance small molecule inhibitors of BCL6 while LLS in collaboration with Melnick continues to explore its role in cancer using peptide inhibitors. It is a two-pronged approach," said Steve Tregay, Forma founder, president and CEO.

Forma was founded in 2007 and is focused on the discovery of cancer therapeutics aimed at high value targets such as protein-protein interactions and tumor metabolism. ${ }^{6}$

Separately, the California Institute for Regenerative Medicine (CIRM) has awarded a \$3.6-million early translational grant to Müschen to develop BCL6 inhibitors to use in combination with TKIs to kill leukemia-initiating cells in Philadelphia chromosome-positive ALL and CML. Müschen told SciBX that this goal can be accomplished either by developing new small molecule inhibitors or by further preclinical development of the existing BCL6 peptide inhibitor.
Melnick has filed for patents covering BCL6 inhibitors. Müschen plans to file for patents covering the use of BCL6 inhibitors in tyrosine kinase-driven leukemias.

Cain, C. SciBX 4(38); doi:10.1038/scibx.2011.1056

Published online Sept. 29, 2011

\section{REFERENCES}

1. Hurtz, C. et al. J. Exp. Med.; published online Sept. 12, 2011; doi:10.1084/jem.20110304

Contact: Markus Müschen, University of California, San Francisco, Calif. e-mail: markus.müschen@ucsf.edu

2. Duy, C. et al. Nature $473,384-388$ (2011)

3. Polo, J.M. et al. Nat. Med. 10, 1329-1335 (2004)

4. Cerchietti, L.C. et al. Blood 113, 3397-3405 (2008)

5. Cerchietti, L.C. et al. Cancer Cell 17, 400-411 (2010)

6. Flanagan, F. BioCentury 17(5), A11; Jan. 26, 2009

COMPANIES AND INSTITUTIONS MENTIONED

Bristol-Myers Squibb Co. (NYSE:BMY), New York, N.Y. California Institute for Regenerative Medicine (CIRM), San Francisco, Calif.

Forma Therapeutics Inc., Cambridge, Mass.

Leukemia \& Lymphoma Society, White Plains, N.Y.

Novartis AG (NYSE:NVS; SIX:NOVN), Basel, Switzerland

Otsuka Pharmaceutical Co. Ltd., Tokyo, Japan

University of California, San Francisco, San Francisco, Calif. Weill Cornell Medical College, New York, N.Y. 